\title{
"Theatre of Fine Devices" - The Visual Imagery of Webster's Tragedies
}

\section{SAMUEL SCHUMAN}

It is the nature of the poetic drama to seek to combine the physical properties of the stage with the verbal imagery of poetry, creating a "stage language" which is both concrete and symbolic. ${ }^{1}$ The tragedies of John Webster, the Jacobean dramatist, are particularly rich in their exploitation of such theatrical imagery. Webster is especially adept in his manipulation of colours, masks, and disguisings in a manner which is complex, dramatically fascinating, and thematically revealing. ${ }^{2}$

The White Devil features several noteworthy disguises of sharp ironic content. Each involves the use of black and white, a striking visual contrast, certainly, and a highly evocative set of colours. These disguises based upon manipulations of colour are carefully set within a rich context of verbal colour imagery.

Much of the chromatic iconography of The White Devil conforms to the traditional values ascribed to black and white: white is used for innocence and purity, black for sin, guilt, and the like. ${ }^{3}$ The conventional framework is important because it provides a background and foundation for Webster's more complex uses of colour, particularly in connection with disguise. It is in this traditional context that we may read statements like these:

FRANCISCO. "proofes of her blacke lust."

(III.i. 6-7)

LAWYER. "such a blacke concatenation of mischief."

FRANCISCO. "a soule so blacke to act a deed so bloudy."

ZANCHE. "I had a hand in the blacke deed."

HORTENSIO. "There's some blacke deed on foot." 
FLAMINEO. "My life was a blacke charnell."

Often such references to blackness conjure up diabolic visions:

MONTICELSO. And some there are which call it my blacke booke:

Well may the title hold: for though it teach not

The Art of conjuring, yet in it lurke

The names of many devils.

(IV.i. 35-38)

or

FRANCISCO. Now to the barriers

This shall his passage to the blacke lake further.

(V. ii. $80-81)$

These verbal colour citations create a kind of imagistic false-front they establish an ethical perspective on characters and actions which Webster actually seeks not to reinforce but to question and demolish. Often, therefore, the traditional values of black and white are strangely reversed - white, for example, can signify danger in a storm:

VITTORIA. My soule, like to a ship in a blacke storme,

Is driven I know not whither.

FLAMINEO.

Then cast ancor.

Prosperity doth bewitch men seeming cleere,

But seas doe laugh, shew white, when Rocks are nere.

(V. vi. 248-251)

Vittoria's words correspond to the predicament she is describing. The verbal conventionality of the image of the "ship in a black storm" is, by virtue of its commonality, a moral beacon or landmark. But Flamineo denies even this sense of place and direction by asserting the "bewitching" reversal in which the glimpse of "white" in the storm offers not a respite from the confusing blackness, but a surprising intensification and heightening of the danger.

Some of the most significant ironic colour reversals occur with disguised characters. In Act V, Francisco, in his role as agent of the murders of Brachiano and Vittoria, appears disguised as Mulinassar, a Moor. While he is disguised, his usual Machiavellian attitude is transmuted, superficially, to a modest and wise Senecan stoicism. His speech becomes selfeffacing, dignified, almost reverent, e.g.,

'Tis a ridiculous thing for a man to bee his owne Chronicle - I did never wash my mouth with mine owne praise for feare of getting a stincking breath. 
Francisco has not only reversed his colour from white to black, he has also disguised his personality. We are presented with an ironic picture (the irony based, rather uncomfortably, upon racist stereotypes) of a white man with a black heart disguised as a black man with a white spirit.

Another interesting reversal of the traditional values of colours occurs in III. ii. when Vittoria is accused by Cardinal Monticelso of failing to mourn properly the recent death of her husband:

Shee comes not like a widow: shee comes arm'd

With scorne and impudence: Is this a mourning habit?

VITTORIA. Had I forknowne his death as you suggest,

I would have bespoke my mourning.

(III. ii. 124-127)

Throughout this scene of intense persecution we are forced into symJathy with Vittoria. ${ }^{4}$ Thus, as the Cardinal invites Vittoria's judges (including, of course, the audience) to consider her costume, he attempts to contrast her appearance with that of the stock figure of the mourning widow. Like a considerably greater, if less spirited, tragic hero before her, Vittoria rejects the notion that the seeming bereavement of an inky cloak, the "show" of loss, is a virtue. The audience is again cast adrift from the world of predictable ethical evaluation and finds itself applauding the rejection of the sombre widow's garb - and with it, the whole constellation of social role-playing and ethical posturing which underlie such traditions.

A final important reversal of black/white values is contained in the title of the play. The "white devil" is Vittoria, and the title is an appropriate one. To Webster's finest editor, F.L. Lucas, the name of the play simply suggests "a devil disguised under a fair outside." ${ }^{5}$ Considering the multiple ironies in Webster's work, and particularly the doubts raised i) so many ways about the viability of conventional morality in the v'orld of The White Devil, the title means much more. The play creates a climate of moral skepticism, suggesting that perhaps the most significant couplet in the work may be Flamineo's:

As in the world there are degrees of evils:

So in this world there are degrees of devils.

(IV. ii. 60-61)

Webster rejects the unthinking and expected conventional moral perspective, the morality in which white is good and black is evil, in which all devils are black and all angels white, and presumably mankind may be divided into devils and angels. To the Puritan, Vittoria may be a devil, but within the harsh climate of Webster's morality of integrity, it is Francisco who is black, and Vittoria is a very "white devil." "Evil wears the mask of good, and good disguises itself as evil." 6 
White and black are not the only colours which Webster utilizes in his attempt to overturn hackneyed morality. In both The White Devil and The Duchess of Malfi, red, particularly the scarlet of the robes of the Cardinals, is important. Red is traditionally associated with blood, and, perhaps as a result, passion. The moral implications of the colour are, therefore, ambivalent. In the case of a Cardinal's clerical outfit, the blood is supposed to be that of Christ and of martyrdom, and stands for the sacrificial love of God. This is a sacramental vision of blood, the blood one drop of which would have purified and saved Marlowe's Faustus. But, on the other side, red is often associated with sins of passion, especially sexual passion, as in the phrase "a scarlet woman." Webster precedes Haw thorne in observing the ways in which the seeming innocence of the clergy can be played off against apparently sexually evil women so as to raise questions about the ethical judgements and stereotypes of society. Both Vittoria and the Duchess are Scarlet Women, both are attacked as sexual criminals by men of the (scarlet) cloth, but in both cases, the red of the women proves an emblem of greater virtue than that worn by their assailants.

Perhaps the most fully developed stage picture of this scarlet-reversalprocess is presented in the arraignment scene in The White Devil already examined. In this scene, Cardinal Monticelso is at his worst. He acts as prosecuting attorney and judge in a case which is patently false. He himself observes,

For sir you know we have nought but circumstances

To charge her with, about her husbands death.

The Cardinal uses every rhetorical tactic to prove Vittoria guilty. Explaining his methods, he sarcastically tells her,

I shall bee playner with you, and paint out

Your folies in more naturall red and white,

Then that upon your cheeke.

VITTORIA.

O you mistake.

You raise a blood as noble in this cheeke

As ever was your mothers.

(III. ii. 54-58)

The Cardinal has informed the audience that his case is both vindictive and artificial, and his actions reinforce his hypocrisy. His statements to Vittoria about colour, then, are sharply ironic. Monticelso, clad for all to see in his bright red robes, is a self-confessed and lying persecutor, yet he pontificates about natural and honest red and white. The red in Vittoria's cheek, though undeniably related to lust and possible murder, 
emerges as a nobler colour than the nominally sacred scarlet of the Cardinal's robes.

Webster's use of masks, disguise, and colour in The Duchess of Malfi is less unified but perhaps even more successful than his manipulation of such visibilia in The White Devil. Of particular note in the later play is Webster's development of a technique wherein a recurrent image begins its life within the drama as a purely verbal phenomenon and acquires, during the course of the action, a concrete manifestation. One illustration of this device may be found in the use of masks in the development of the character of Bosola. ${ }^{7}$

When we first meet this complex and ambiguous malcontent, he is hired by the Aragonian brothers to spy on the Duchess. He is offered this job at least in part on the basis of appearance: "some oblique character in your face" (I. i. 247). This motif - the stressing of Bosola's "looks" - continues as, clad in a "garbe of melencholly" (I. i. 303), he describes his new employment as essentially a matter of disguise, of making himself "a very quaint invisible Divell, in flesh: an Intelligencer" (I. i. 280-281). ${ }^{8}$ Throughout the successful performance of his tasks, he and others around him often refer to his "counterfeit face" (III.v. 142). When his work reaches its odious climax, the murder of the Duchess, the previously figurative disguise assumes a visible reality. Immediately after the grotesque Masque of Madmen, Bosola appears with a literally counterfeit face:
Bosola (Like an old man) enters.
DUCHESS. Is he mad too?
SERVANT' 'Pray question him: I'll leave you.
BOSOLA. I am come to make thy tombe.

(IV. ii. 112 s.d.-115)

But after the Duchess dies, Bosola undergoes a change of heart, more fully developed but similar to that of Flamineo in The White Devil: he recognizes in his victim a spirit more kindred than those of his allies. He removes both his literal and figurative masks, saying,

I stand like one

That long hath ta'ne a sweet, and golden dreame.

I am angry with my selfe, now that I wake.

Yet, I lov'd

You that did councell it: and rather sought

To appeare a true servant, then an honest man.

Off my painted honour! 
Bosola seems to be suggesting that his former "face" was indeed a disguise, in which he was perhaps masked even to himself. We (and he) had thought we knew the real countenance lurking beneath the masks in which figuratively, then literally, he confronted the Duchess. But Bosola discovers and we discover with him that that appearance was also fraudulent. The unfeeling schemer and murderer disguised as the loyal servant turns out to have been a human being with some sensitivity and a sense of justice, who only seemed an amoral and uncaring Machiavellian.

A similar progression from verbal to visual imagery in The Duchess of Malfi may be found in Webster's use of animal motifs. The use of bestial imagery to describe human behaviour and emotions is, of course, not limited to Webster. It is a technique at least as ancient as the Homeric epic, and used to great effect by such other Renaissance playwrights as Shakespeare and Jonson. But, surely, Webster's treatment of the wolf image in The Duchess of Malfi is unique. The theme of human wolfishness is introduced by Bosola during his soliloquy on man: "What thing is in this outward forme of man?" (II. i. 47) Bosola asks himself, and his response includes the observation.

But in our owne flesh, though we beare diseases

Which have their true names onely tane from beasts,

As the most ulcerous Woolfe.

Later, Ferdinand says to the Duchess,

The howling of a Wolfe

Is musicke to thee (schrech-Owle) pre'thee peace.

(III. ii. 105-106)

It is also Ferdinand who says in the next act, when he "Shews the children strangled,"

The death

Of young Wolffes, is never to be pittied.

(IV. ii. 274-275, s.d.)

And later, he says to Bosola, speaking of the dead Duchess,

Oh, I'll tell thee:

The Wolfe shall finde her Grave, and scrape it up.

(IV. ii. 331-332)

Finally, this verbal imagery becomes concrete theatrical reality, as Ferdinand succumbs to 
A very pestilent disease (my Lord)

They call Licanthropia. PESCARA. What's that?

I need a Dictionary to't. DOCTOR. I'll tell you:

In those that are possess'd with't there ore-flows

Such mellencholy humour, they imagine

Themselves to be transformed into Woolves.

(V.ii. 6-11)

Ferdinand's wolf imagery has developed into an obsession which deforms an already distorted personality. "The animality of Ferdinand's nature forces itself to the surface in the horrible form of lycanthropy." 90 the extent that Webster could show a man actually becoming a wolf on stage, Ferdinand is transformed.

In a recent, rather conservative, production of the play on National Educational Television, for example, the previously dapper Ferdinand suddenly appears clad in many furs, hair and body unkempt, growling, drooling, and carrying raw meat as a hand prop. ${ }^{10}$ Surely figurative language has rarely been translated into such hideous and concrete stage pictures. Here, once again, the verbal becomes the visual, a grotesque emblem of the degradation possible to human nature.

The constant use of masks, deceptive colours, and "all kinds of disguise," 11 in both The Duchess of Malfi and The White Devil, reveals Webster's central preoccupation with the "false show." Nothing in Webster's universe is ever what it seems to be. Particularly in the realms of personality and morality, appearance, with its aura of normalcy and zonventionality, is deceptive in the extreme. Webster, concerned with the falseness of the conventional norms and the moral duplicity of his ociety and its people, is very predictably concerned with the frequent :onflict between appearance and reality. This conflict is manifested in hypocrisy and revealed through irony. The emblematic devices so careiully used by Webster allow him to focus upon appearance, while the subversion of the hackneyed emblem morality, so often revealed in his larger dramatic context, allows him to show the bleak reality which, like the skull beneath the skin, lurks always just below the surface.

\section{University of Maine at Orono}

\section{Footnotes}

1 The ground-breaking studies of theatrical imagery include Alan S. Downer, "The Life of Our Design: The Function of Imagery in the Poetic Drama," in Shakespeare, Modern Essays in Criticism, ed., L. Dean (New York, 1961), pp. 19-36, and Maurice Charney's discussion of "presentational imagery" in Shakespeare's Roman Plays (Cambridge, Mass., 1961), pp. 4-10, e.g. ". . .the large body of images that is not part of the spoken words of the text, but directly presented in the theater. Some synonyms might be 'dramatic metaphor' or 'stage image' (as contrasted with 'verbal' images)," p. 8. All citations to Webster are from The Complete 


\section{4 / Renaissance and Reformation}

Works of John Webster, ed. F.L. Lucas (New York, 1927). Since this essay was written, I have become familiar with Anders Dalby's The Anatomy of Evil: A Study of John Webster's "The White Devil," (Lund, 1974), in which some similar aspects of colour usage in the tragedies are discussed. Fortunately, Dalby's methods and conclusions differ considerably from my own.

2 In "The Ring and the Jewel in Webster's Tragedies," Texas Studies in Literature and Language, 14 (1972), 253-68, I discuss Webster's use of symbolically significant "props" in The White Devil and The Duchess of Malfi.

3 D.C. Allen, "Symbolic Colors in the Literature of the English Renaissance," PQ, 15 (1936), 81-92. One of only four Renaissance treatises on symbolic colour is included in the 1580 edition of A. Alciati's emblem book.

4 See H.B. Franklin, "The Trial Scene of Webster's The White Devil Examined in Terms of Renaissance Rhetoric," SEL 1 (Spring, 1961), 35-51.

5 Works, I. 193. Note also the phrase, "the whiter the fouler," a description of the Duchess of Malfi found at III. iii. 65.

6 I. Ribner, Jacobean Tragedy (London, 1962), p. 108.

7 See C.G. Thayer, "The Ambiguity of Bosola," SP 54 (1957), esp. pp. 170-71. Note also E.M. Brennen, ed., The Duchess of Malfi (N.Y., 1966), p. xxiv: "The conflict between appearance and reality. . is found in Bosola, in whom it is made visible through the use of disguises, though they are in fact less important than the invisible disguising of his true nature at the beginning of the play."

8 It is interesting, and by no means irrelevant to the study of Webster's career as literary artist, that the word "devil" appears as often in The Duchess of Malfi as in The White Devil itself. I have noted 37 occurrences of the word in the former play.

9 Brennen, p. xiii.

10 This production was televised and re-televised as a segment of the series "Classic Humanities Theater." A very similar staging of the lycanthropic scenes was presented in the 1971 Stratford, Ontario, version.

11 Franklin, p. 35. 